\title{
The Effect of Innovation, Promotion, and Quality of Products on Consumer Loyalty with Satisfaction as Intervening Variables (Case Study Costumer PT. Mandom In Surabaya)
}

\author{
Rega Irsa Irawan* \& Sengguruh Nilowardono
}

Faculty of Economics and Business, Narotama University, Surabaya, Indonesia

\begin{abstract}
This study aims to determine the effect of innovation, promotion, product quality on consumer loyalty with customer satisfaction as intervening. This research method uses quantitative with OLS analysis tools. The research instrument was a questionnaire with 75 samples of Gastby product consumers. The results of the study prove that Innovation has positive significant effect on consumer satisfaction as evidenced by the results of $t$ value of 4.457 with p-value of 0.00 , Innovation has significant positive effect on consumer loyalty as evidenced by the results of $t$ value of 8.897 with p-value amounting to 0,000 , promotion does not have a significant positive effect on customer satisfaction $t$ value of 0.421 with p-value of 0.674 , promotion does not have a significant positive effect on consumer loyalty as evidenced by the result of $t$ of 1,277 with $p$-value of 0,202 , quality the product has significant positive effect on customer satisfaction as evidenced by the results of $t$ table (1.666) and $p$-value smaller than 0.05 , product quality has significant positive effect on loyalty consumer as evidenced by the results of this value greater than $t$ table (1.666 ) and p-value is smaller than 0.05 consumer power has an effect on consumer loyalty as evidenced by the results of $t$ value of 4.689 with a p-value of 0.00 .
\end{abstract}

Keywords: Innovation; promotion; product quality; consumer loyalty; customer satisfaction.

\section{Introduction}

The growing business world, competition in the business world even more tight. This can be seen from the number of new businesses that have emerged, especially in the city of Surabaya. Business people areeach other competing withto offer various advantages of the products they market. This fact certainly encourages companies to continue to maximize the performance of their company, so that the company can continue to maintain and even improve the quality and quantity of products produced. Determining strategy the right marketing is an obligation that must be done by every company. By determining the marketing strategy right, this can support companies to be able to compete with other competitors. So that it can enhance competitive advantage that is sustainable and can satisfy consumer desires. the Thus purpose of the company can be reached. The main key for the company to win the competition is to give satisfaction to customers, one of them is through innovation, promotion, and good product quality. By giving satisfaction to customers, it is expected that customers will make purchases repeatedly so that loyalty is formed customer

With the satisfaction and loyalty of customers, it will provide long-term benefits to the company. This is what makes the companies, especially in the field of male cosmetics competing to maintain customer satisfaction and loyalty so as not to switch to competitors other. The increase in the number of competitors in products has men's cosmetic caused intense competition. The company must understand and carry out the right marketing strategy to win the competition, if not then the company will lag behind the existing competitors and eventually cause producers to lose their

\footnotetext{
* Corresponding author.

E-mail address: reyga007@hotmail.com (Rega Irsa Irawan)
} 
customers. One of the male cosmetics companies that feels the tight competition is Gatsby.

Gatsby is one of the products cosmetic from PT. MANDOM was welcomed enthusiastically by the people of Surabaya. Of the many choices of male cosmetics in Surabaya, many things are considered by consumers to come to the decision to choose cosmetic products. The management of PT. MANDOM must strive to meet all the criteria that are considered by consumers, be it innovation, promotion and product quality that can affect consumer satisfaction with consumer loyalty. If this is ignored, then there will be an imbalance between desires (expectations) of what feel consumers that the impact will directly affect the decline in customer satisfaction and will then continue to decrease consumer loyalty. Therefore, the success or failure of gatsby products on the market depends on innovation, promotion and product quality that can affect consumer satisfaction with consumer loyalty to gatsby products, although there are many cosmetic competitors male who provide similar products. Based on the financial statements of PT Mandom Indonesia Tbk. 2018 audited released on Wednesday (03/20/2019), the issuer with code TCID stock recorded net sales of Rp2.65 trillion, down $2.13 \%$ compared to the previous year amounting to Rp2.71 trillion. make concrete steps to hoist sales, one of them is by creating innovation, innovation must be created by the company because innovation is one of the sources of the company's growth. Product innovation is one of the most reliable factors by a marketer in marketing a product. Innovation will increase the added value of a product, innovation will create a new product that can provide a better solution for solving problems faced by consumers (Masda, 2012).

\section{Research Objective}

a) To analyze the effect of innovation on consumer satisfaction.

b) To analyze the effect of innovation on consumer loyalty.

c) To analyze the effect of promotion on customer satisfaction.

d) To analyze the effect of promotion on consumer loyalty.

e) To analyze the effect of quality product on customer satisfaction.

f) To analyze the effect of quality product on loyalty consumer

g) To analyze the effect of innovation, promotion, product quality on consumer loyalty with customer satisfaction as an intervening

\section{Literature Review}

\subsection{Innovation}

Crawford \& Di Benedetto, (2000) states that product innovation is an innovation used in the who operations company where a new product is created and marketed, including innovation in all processes functional/ uses. Product innovation is something that can be seen as a functional advancement of a product that can bring a product a step ahead of its competitors' products. Products that have advantages have added value to consumers Neely et al (1995) argue that product innovation shows the development and introduction of new or developed products that are successful in marketing. Product innovation can be a change in design, components and product architecture.

\subsection{Promotion}

Promotion is the core ingredient in marketing campaigns, consisting of a collection of incentive tools, mostly shortterm, designed to stimulate larger buyers of certain products or services by consumers or traders (Kotler, 2008). According to Alma (2007) that Promotion is a type of communication that provides an explanation that convince prospective consumers of goods and services. Swastha (2008) that promotion is a flow of information or persuasion in one direction that is made to inform someone or organization to actions that create exchange in marketing.

\subsection{Product Quality}

According to Kotler, et. al. (2000), "Product quality is a characteristic and characteristic of an item or service that affects its ability to satisfy expressed or implied needs". Whereas according to Adam \& Eberts (1992) "Product quality is the appropriateness of the design specification of the function and use as well as the specification 
specification." The above is the overall characteristic combination of definition explains that product quality is design specification the right or that is feasible to use as best as possible according to specifications. According to Feingenbaum (1992) product quality is product from marketing, engineering, fabrication and maintenance that makes the products used meet customer expectations. So product quality is a number of attributes or properties described in the product (goods and services) and used to meet customer expectations.

\subsection{Consumer Loyalty}

According to Tjiptono, Fandy, \& Anastasia (2011), loyalty consumer is purchase of a brand consistent by consumers.loyalty. Consumer can arise because of customer satisfaction as a result of services quality that meet customer expectations so that they do not switch to other products. Maintaining consumers themselves is an important part of creating loyalty customeris not an easy thing, because companies must look at all dimensions of business and determine how it should create value for consumers. By creating value for consumers it will build consumer loyalty and maintain it.

Griffin (2002) says that loyal consumers are people who: (1) Do repeat purchases, (2) Buy between product lines and services, (3) Refer to others. The factors that influence Consumer Loyalty according to Vanessa Gaffar (2007) consist of 5 factors, namely: (1) Satisfaction, (2) Emotional bonding, (3) Trust, (4) Ease (reduction awards and habit), (5) Experience with the company (history with company).

\subsection{Consumer Satisfaction}

According to Sunyoto (2014) the definition of customer is the satisfaction level of satisfaction of a person after comparing (performance or results) that is felt compared to his expectations. The level of satisfaction is a function of the difference between perceived performance and expectations. consumers can understand one of the three levels of general satisfaction, namely if the performance is below expectations, consumers will feel disappointed, but the performance is in line with the expectations the customer will feel satisfied and if the performance can exceed expectations, the customer will feel very satisfied happy or very happy.

Whereas according to Sunyoto (2014) customer expectations are to play an important role and very large influence in determining the quality of products (goods and services) and customer satisfaction in evaluating customers will use their expectations as a standard or reference, thus the expectations of consumers / customers are the background why two organizations in the same business can be valued differently by consumers.

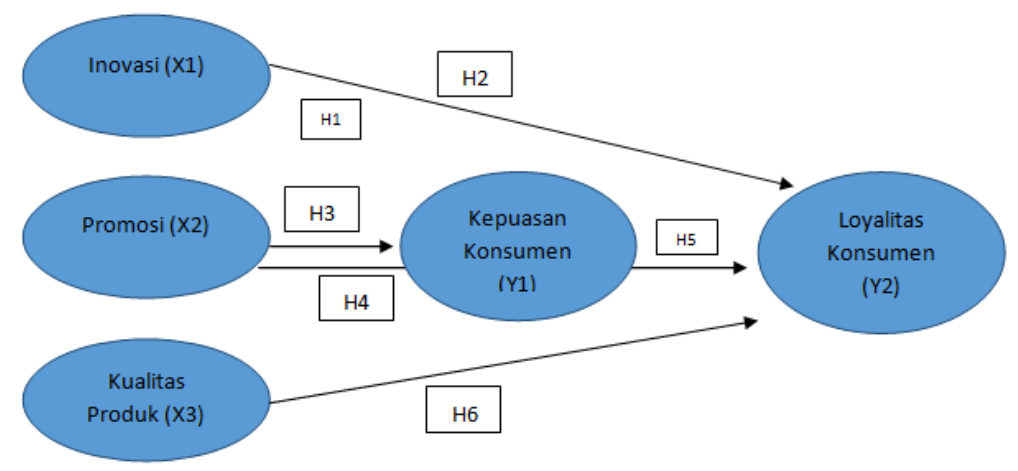

Fig. 1. Conseptual Framework (in Indonesia)

\section{Hypothesis}

- H1: Innovation has a significant positive effect on customer satisfaction.

- H2: Innovation has a significant positive effect on consumer loyalty. 
- H3: Promotion has a significant positive effect on customer satisfaction.

- H4: Promotion has a significant positive effect on consumer loyalty.

- H5: Product quality has a significant positive effect on customer satisfaction.

- H6: Product quality has a significant positive effect on consumer loyalty.

- H7: Consumer satisfaction has apositive significanteffect on consumer loyalty.

\section{Methods}

Approach of this study uses quantitative research approach that is much demanded to use numbers, starting from data collection, interpretation of the data, and the appearance of the results. In this quantitative research there are 5 variables, namely innovation, promotion, product quality satisfaction, consumer, consumer loyalty.

The type of data used in this study are: quantitative data is a research method based on the philosophy of positivism, used to examine certain populations or samples. Sampling techniques are generally carried out randomly, data collection uses research instruments data analysis quantitative/statistics with the aim to test the hypothesis that has been set (Sugiyono, 2013). In this study researchers used PLS data analysis techniques using SmartPLS Partial Least Squares (PLS) Software often referred to as soft modeling because it eliminated OLS (Ordinary Least assumptions Squares) regression, as data must be distributed normally in a multivariate manner and no problems multicoloniality between variables (Ghozali, 2006).

\section{Result and Discussions}

In this study, researchers using this study are quantitative data because in collecting information using questionnaires directly distributed to consumers PT. Mandom in Surabaya. The type of data used in quantitative research methods can be interpreted as a powerful analytical method and PLS data analysis techniques using SmartPLS Software Partial Least Squares (PLS) are powerful analytical methods and are often referred to as soft modeling because they exclude OLS (Ordinary) assumptions. Least Squares) regression, as data must be distributed normally in a multivariate manner and there is no problem multicollinearity between variables. Here are the results of the research obtained.

\subsection{Discriminant validity}

Discriminant validity is done to ensure that each concept of each latent variable is different from other variables.

Table 1. Discriminant Validity (Cross Loading)

\begin{tabular}{lccccc}
\hline & Latent Variable 1 & Latent Variable 2 & Latent Variable 3 & Latent Variable 4 & Latent Variable 5 \\
\hline ItemX1.1 & 0,920 & 0,850 & 0,719 & 0,751 & 0,859 \\
itemX1.2 & 0,787 & 0,647 & 0,407 & 0,815 & 0,724 \\
itemX1.3 & 0,865 & 0,793 & 0,882 & 0,760 & 0,870 \\
itemX2.1 & 0,744 & 0,828 & 0,564 & 0,780 & 0,776 \\
itemX2.2 & 0,670 & 0,835 & 0,800 & 0,570 & 0,698 \\
itemX2.3 & 0,848 & 0,890 & 0,855 & 0,728 & 0,849 \\
itemX3.1 & 0,813 & 0,859 & 0,926 & 0,660 & 0,862 \\
itemX3.2 & 0,395 & 0,466 & 0,514 & 0,602 & 0,439 \\
\hline
\end{tabular}


Irawan, et.al | Quantitative Economics and Management Studies (QEMS), 2021, 2(3): 206-213

\begin{tabular}{cccccc}
\hline & Latent Variable 1 & Latent Variable 2 & Latent Variable 3 & Latent Variable 4 & Latent Variable 5 \\
\hline itemX3.3 & 0,535 & 0,607 & 0,824 & 0,421 & 0,640 \\
itemY.1 & 0,837 & 0,772 & 0,779 & 0,879 & 0,903 \\
itemY.2 & 0,813 & 0,859 & 0,926 & 0,660 & 0,862 \\
itemY.3 & 0,799 & 0,713 & 0,508 & 0,857 & 0,795 \\
itemZ.1 & 0,812 & 0,696 & 0,483 & 0,846 & 0,768 \\
itemZ.2 & 0,284 & 0,336 & 0,398 & 0,571 & 0,362 \\
itemZ.3 & 0,837 & 0,772 & 0,779 & 0,879 & 0,903 \\
\hline
\end{tabular}

From table 1, it can be seen that the value of loading factors for each indicator of each variable ten has the loading factor greatest value if it is associated with other latent variables. This means that any latent variables have discriminant validity was good.

\subsection{Reliability and Average Variance Extracted (AVE)}

Criterion validity and reliability can also be seen from the reliability of a construct and value Average Variance Extracted (AVE).

Table 2. Composite Reliability and Average Variance Extracted

\begin{tabular}{lcccc}
\hline & Cronbach's Alpha & rho_A & Composite Reliability & Average Variance Extracted (AVE) \\
\hline Latent Variable 1 & 0,820 & 0,822 & 0,894 & 0,738 \\
Latent Variable 2 & 0,811 & 0,819 & 0,888 & 0,725 \\
Latent Variable 3 & 0,628 & 0,701 & 0,810 & 0,600 \\
Latent Variable 4 & 0,684 & 0,773 & 0,816 & 0,605 \\
Latent Variable 5 & 0,814 & 0,819 & 0,890 & 0,731 \\
\hline
\end{tabular}

Based on the table 2 can be concluded that all constructs reliably meet the criteria for testing inner model or models structural made to look at the relations between constructs value and the significance R-square of the research model, the structural model is evaluated using $\mathrm{R}$-square for the dependent construct $\mathrm{t}$ test and the significance of the structural path parameter.

In assessing the model with PLS begins by looking at R-square Adjusted for each dependent latent variable. Figure 2 is the result of estimation Adjusted R-square using SmartPLS. 


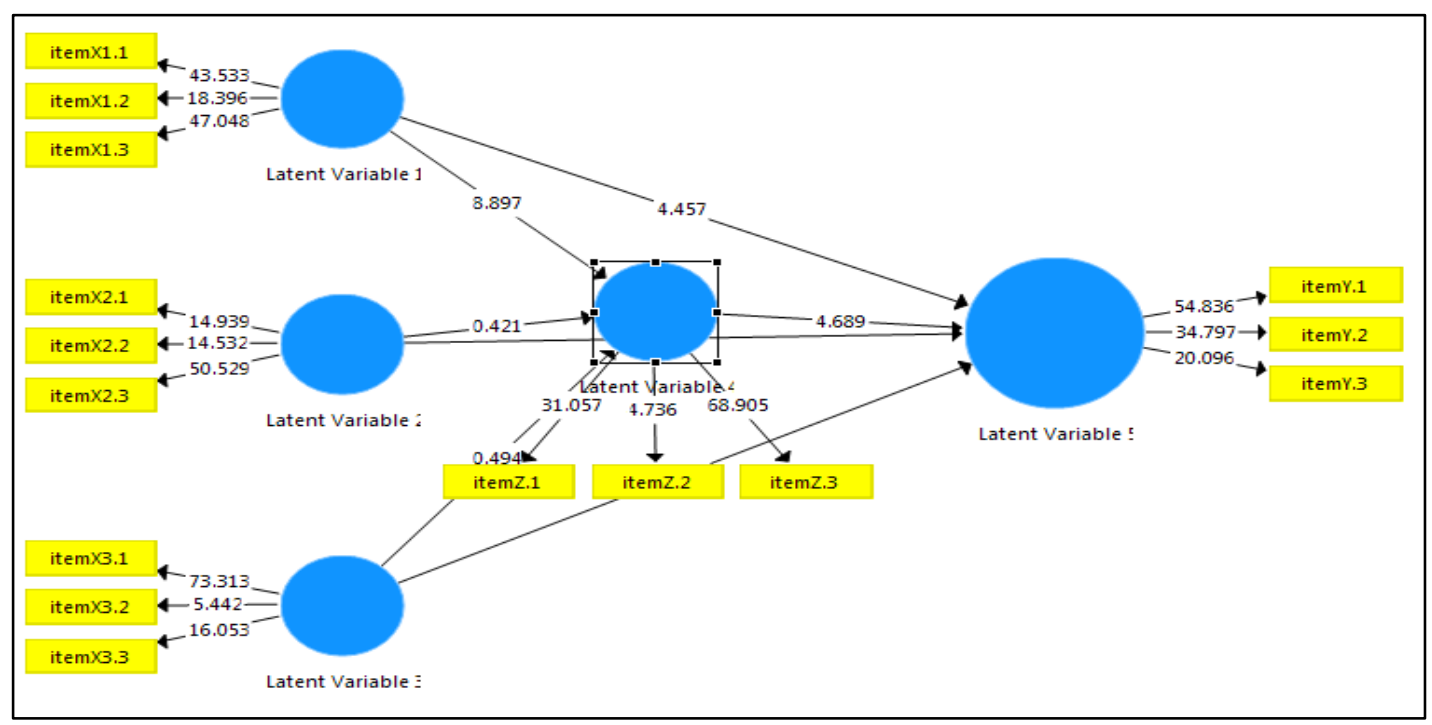

Figure 2 Structural Model

Table 3. R Square Adjusted

\begin{tabular}{lll}
\hline & R Square & R Square Adjusted \\
\hline Latent Variable 4 & 0,817 & 0,809 \\
Latent Variable 5 & 0,971 & 0,969 \\
\hline
\end{tabular}

In this study consisted of five variables: independent variable: Innovation(X1), Service Quality (X2), Product Quality (X3), intervening variable: Customer Satisfaction (Y1), and dependent variable: Consumer Loyalty (Y2). Table 3 shows the value of $\mathrm{R}$ Square Adjusted for the Customer Satisfaction variable (Y1) obtained at 0.817 for Loyalty Consumer (Y2) obtained at 0.971 . These results indicate that $81.7 \%$ of the Satisfaction Consumer (Y1) can be influenced by Innovation (X1), Promotion (X2), and Product Quality (X3) while Consumer Loyalty (Y2) can be influenced by the Innovation (X1), Quality Service (X2), and Product Quality (X3) with a value of 97.1\%

\subsection{Hypothesis Testing}

Table 4. Value Path coefficient

\begin{tabular}{|c|c|c|c|c|c|}
\hline & $\begin{array}{c}\text { Original } \\
\text { Sample }(\mathbf{O})\end{array}$ & $\begin{array}{c}\text { Sample Mean } \\
\text { (M) }\end{array}$ & $\begin{array}{c}\text { Standard Deviation } \\
\text { (STDEV) }\end{array}$ & $\begin{array}{c}\text { T Statistics } \\
(|\mathrm{O} / \mathrm{STDEV}|) \\
\end{array}$ & $\begin{array}{c}\mathbf{P} \\
\text { Values } \\
\end{array}$ \\
\hline $\begin{array}{l}\text { Latent Variable } 1 \text {-> Latent } \\
\text { Variable } 4\end{array}$ & 0,825 & 0,833 & 0,093 & 8,897 & 0,000 \\
\hline $\begin{array}{l}\text { Latent Variable } 1 \text {-> Latent } \\
\text { Variable } 5\end{array}$ & 0,378 & 0,364 & 0,085 & 4,457 & 0,000 \\
\hline $\begin{array}{l}\text { Latent Variable } 2 \text {-> Latent } \\
\text { Variable } 4\end{array}$ & 0,044 & 0,035 & 0,105 & 0,421 & 0,674 \\
\hline $\begin{array}{l}\text { Latent Variable } 2 \text {-> Latent } \\
\text { Variable } 5\end{array}$ & 0,077 & 0,083 & 0,060 & 1,277 & 0,202 \\
\hline $\begin{array}{l}\text { Latent Variable } 3 \text {-> Latent } \\
\text { Variable } 4\end{array}$ & 0,349 & 0,351 & 0,059 & 3,494 & 0,021 \\
\hline $\begin{array}{l}\text { Latent Variable } 3 \text {-> Latent } \\
\text { Variable } 5\end{array}$ & 0,254 & 0,254 & 0,040 & 6,277 & 0,000 \\
\hline $\begin{array}{l}\text { Latent Variable } 4 \text {-> Latent } \\
\text { Variable } 5\end{array}$ & 0,342 & 0,348 & 0,073 & 4,689 & 0,000 \\
\hline
\end{tabular}


Irawan, et.al| Quantitative Economics and Management Studies (QEMS), 2021, 2(3): 206-213

\section{Testing Hipotesis 1 (Innovation has a significant positive effect on Consumer Satisfaction)}

The results of the first hypothesis testing show that the effect of thevariable Innovation(X1) on Consumer Satisfaction (Y1) shows a t value of 4.457 with a p-value of 0,000 . This value is greater than $t$ table (1.666) and $p$-value is smaller than 0.05. This result means that Innovation has apositive significantinfluence on Consumer Satisfaction (Y1). This means that Hypothesis 1 is accepted.

\section{Testing Hypothesis 2 (Innovation has a significant positive effect on Consumer Loyalty)}

The results of testing the second hypothesis indicate that the effect of the variable Innovation (X1) on Consumer Loyalty (Y2) shows a t value of 8.897 with a p-value of 0,000 . This value is greater than t table (1.666) and p-value is smaller than 0.05 . This result means that Innovation has positive significant effect on Customer Satisfaction. This means that Hypothesis 2 is accepted.

\section{Testing Hypothesis 3 (Promotion of a significant positive effect on Satisfaction Consumer)}

The results of the testing of the third hypothesis indicate that the effect of thevariable Innovation (X2) on Consumer Satisfaction (Y1) shows a t value of 0.421 with a p-value of 0.674 . This value is smaller than t table (1.666) and pvalue is greater than 0.05 . This result meansdoes that promotionnot have apositive significanteffect on customer satisfaction. This means that Hypothesis 3 is rejected.

\section{Testing Hypothesis 4 (Promotion of a significant positive effect on Loyalty Consumer)}

The results of testing the fourth hypothesis indicate that the effect of the variable Innovation shows $t$ with p- value of 1,277 value of 0,202 . This value is smaller than this result means that the promotion does not have a significant positive effect on Loyalty Consumer. This means that Hypothesis 4 is rejected.

\section{Testing Hypothesis 5 (Quality Product has a significant positive effect on Consumer Satisfaction)}

The results of the fifth hypothesis testing indicate that the effect of the Quality Product(X3) on Consumer Satisfaction (Y1) shows $t$ value of 3.494 with $\mathrm{p}$ - value of 0.021 . This value is greater than of the this result means that the quality product does not have a significant positive effect on (X2) on Consumer Loyalty $(\mathrm{Y} 2), \mathrm{t}$ table $(1,666)$ and p-value greater than 0.05, $\mathrm{t}$ table $(1,666)$ and $\mathrm{p}$-value smaller than 0.05. Consumer satisfaction. This means that Hypothesis 5 is accepted.

\section{Testing Hypothesis 6 (Quality Producthas a significant positive effect on Consumer Loyalty)}

The results of testing the third hypothesis indicate that the effect of the Quality variable Product(X3) on Consumer Loyalty (Y2) shows t value of 6.277 with p- value of 0.00 . This value is greater than $t$ table (1.666) and p-value is smaller than 0.05 . This result means that Product Quality has a significant positive effect on Loyalty Consumer. This means that Hypothesis 6 is accepted.

\section{Testing Hypothesis 7 (Satisfaction Consumerhas a significant positive effect on Consumer Loyalty)}

The results of testing the third hypothesis indicate that the influence of the variable Consumer Satisfaction (Y1) on Loyalty Consumer (Y2) shows $t$ value of 4.689 with p-value of 0.00 . This value is greater than $t$ table (1.666) and $p$ value is smaller than 0.05. This result means that Consumer Satisfaction has positive significant effect on Consumer Loyalty. This means Hypothesis 7 is accepted

\section{Conclusions}

Based on the conclusions above, some suggestionsexpected that can becan be useful for Mandom producers. The suggestions given include: The results of research that show a positive influence of innovation and product quality on consumer satisfaction, then producers continue to develop innovations wherever possible in terms of variants and types of products so consumers are more satisfied. Loyalty that is influenced by innovation and quality can be the 
focus of the development of strategies compared to the promotion of the two factors that significantly affect the loyalty ofproduct consumers Mandom. The findings of the study that showed no influence from promotion on satisfaction and customer loyalty of Mandom products could be interpreted as consumers not really knowing the promotions available so that there was a need for an evaluation of the promotion strategy that had been running at this time.

\section{References}

Grady, J. S., Her, M., Moreno, G., Perez, C., \& Yelinek, J. (2019). Emotions in storybooks: A comparison of storybooks that represent ethnic and racial groups in the United States. Psychology of Popular Media Culture, 8(3), 207-217. https://doi.org/10.1037/ppm0000185

Crawford, M. C. and Di Benedetto, A. C. (2000). New Products Management (6th ed.). Boston, MA: McGraw- Hill

Neely, A., Gregory, M., \& Platts, K. (2005). Performance measurement system design: A literature review and research agenda. International journal of operations \& production management, 25(12), 1228-1263.

Kotler, P. (2008). Marketing management: A south Asian perspective. Pearson Education India.

Alma, B. (2007). Manajemen Pemasaran dan Pemasaran Jasa. Bandung: CV. Alfabeta.

Swastha, Basu \&Irwan. (2008). Manajemen Pemasaran Moderen. Yogyakarta: Liberty.

Kotler, P., Armstrong, G., Saunders, J., Wong, V., Miquel, S., Bigné, E., \& Cámara, D. (2000). Introducción al marketing. Pearson Prentice Hall.

Adam, E.E. and Ebert, R.J. (1992),Production and Operations Management, Prentice-Hall,Upper Saddle River, NJ.

Feigenbaum. (1992). Quality Management. Jakarta : PT. Gramedia Pustaka Utama.

Tjiptono, Fandy, \& Anastasia, D. (2011). Total Quality Management. Yogyakarta: Andi.

Griffin, J. (2002). Customer loyalty: How to earn it, how to keep it. San Francisco, CA: Jossey-Bass.

Vanessa, G. (2007). Customer Relationship Management and Marketing Public Relations. Bandung: Alfabeta.

Sunyoto, D. (2014). Teori, Kuesioner dan Analisi Data untuk Pemasaran dan Perilaku Konsumen. Yogyakarta : Center for Academic Publishing Service.

Sugiyono. (2013). Metode Penelitian Bisnis. Bandung: Alfabeta.

Ghazali, I. (2006). Aplikasi analisis multivariate dengan program SPSS. Semarang: Badan Penerbit Universitas Diponegoro. 